|||||||||||||||||||||||||||||||||||

\title{
塩化アルミニウム水溶液中に打ける $\mathrm{Al}-\mathrm{Fe}$ 合金の 腐食電位の検討*
}

世利修美** ·田頭孝介**

An investigation on corrosion potential of

$\mathrm{Al}-\mathrm{Fe}$ alloys in $\mathrm{AlCl}_{3}$ solution

Osami SERI and Kohsuke TAGASHIRA

\begin{abstract}
Effects of iron on the corrosion potential and behavior of $\mathrm{Al}-\mathrm{Fe}$ alloys corroded in deaerated $0.1 \mathrm{M} \mathrm{AlCl}_{3}$ solution were studied by electrochemical measurements. Iron in $\mathrm{Al}-\mathrm{Fe}$ alloys in the form of intermetallic compound dissolves into $\mathrm{AlCl}_{3}$ solution and deposits on the surface of aluminum in the solution. The cathodic reaction of hydrogen evolution easily occurs on the surface of the deposited iron. The aluminum matrix therfore remains a pitting corrosion state, where the corrosion potential is equivalent to the pitting corrosion potential $-0.78 \mathrm{~V}$ vs. Ag/AgCl.
\end{abstract}

Keywords: corrosion potential, $\mathrm{Al}-\mathrm{Fe}$ alloy, $0.1 \mathrm{M} \mathrm{AlCl}_{3}$ solution, immersion test, electrochemical measurement

(Received December 12, 1986)

\section{1. 緒言}

塩素イオンを含有した自然水環境中でのアルミニウム の腐食は孔食を主体とした局部腐食の形態で進行するの が通常である。食孔内環境は脱気した塩化アルミニウム 水溶液で近似できる1)。したがって，アルミニウムの腐 食研究に打いては，食孔内溶液近似としての塩化アルミ ニウム水溶液中のアルミニウム合金の電気化学的挙動を 把握することが重要な課題の一つになってくる2)。

一般に, 自然腐食状態に抢ける金属材料の電気化学的 挙動を把握するには腐食電位の長期追跡が有用である ${ }^{3)}$ 。 $\mathrm{Al}-\mathrm{Fe}$ 合金の孔食過程でも塩化アルミニウム水溶液中に おける腐食電位の变化は, $\mathrm{Al}-\mathrm{Fe}$ 合金の局部腐食挙動に 関する電気化学的情報を反映して変化しているはずであ る。

本報では, 脱気処理した塩化アルミニウム水溶液中に $\mathrm{Al}-\mathrm{Fe}$ 合金を浸漬し，その腐食電位の経時変化を長期飞 わたって追跡した。得られた腐食電位変化を食孔内に拀 ける電気化学的挙動の変化を反映したものとしてとらえ なおし，その腐食電位の意味付けを行い，興味ある知見 を得た。 $\mathrm{Al}-\mathrm{Fe}$ 合金の腐食における基礎データの蓄積と
整備の一環として，得られた知見を報告する。

\section{2. 実験方法}

\section{1 供試材}

$\mathrm{Al}-\mathrm{Fe}$ 合金の化学分析值を Table 1 亿示す。

試片の作製は高純度アルミニウム $(99.97 \% \mathrm{Al})$ 飞鉄 を添加し, 溶解, 鋳造後, 均質化処理 $\left(540^{\circ} \mathrm{C} て ゙ 160\right.$ 時 間保持, 後炉冷) を経て, 熱間および冷間圧延を行い,

厚さ $1 \mathrm{~mm}$ の板とした。

各試片の前処理はアルカリ洗浄 $\left(70^{\circ} \mathrm{C}\right.$ の $10 \% \mathrm{NaOH}$ 水溶液で 1 分間浸漬）を行い, 水洗後, 中和処理（室温

Table 1 Chemical composition of specimens

\begin{tabular}{c|c|c|c}
\hline \hline \multirow{2}{*}{$\begin{array}{c}\text { Specimen } \\
\text { No. }\end{array}$} & \multicolumn{3}{|c}{ Chemical composition (wt\%) } \\
\cline { 2 - 4 } & $\mathrm{Fe}$ & $\mathrm{Si}$ & $\mathrm{Al}$ \\
\hline $\mathrm{F} 1$ & 0.32 & 0.10 & bal. \\
F2 & 0.59 & 0.09 & $\mathrm{bal}$. \\
$\mathrm{F} 3$ & 1.04 & 0.10 & $\mathrm{bal}$. \\
$\mathrm{F} 4$ & 1.45 & 0.11 & $\mathrm{bal}$. \\
$\mathrm{Fe}$ & 99.9 & tr. & tr. \\
\hline
\end{tabular}

* 軽金属学会秋期大会講演 (1986-11) 飞て一部発表。

** 室蘭工業大学 (室蘭市)。Muroran Institute of Technology（Muroran)。 
の $30 \% \mathrm{HNO}_{3}$ 水溶液で 1 分間浸漬）を施し，十分な水 洗, 乾燥の後, 測定に供した。

実験終了後，試料表面に付着した腐食生成物は脱膜処 理4)を行い，溶解除去した。

\section{2 試験液}

試験液はイオン交換水を用いた。その容量は総て $1 l$ とした。試薬は特級を用い，所定の濃度に作製し，実験 に供した。溶存酸素の除去方法としては，溶液擋䢁状態 下にて窒素ガスを流して执いた。

\section{3 測定方法}

分極曲線の測定は通常のポテンシオスタットを用いる 動電位法で行い, 電位掃引速度は $0.4 \mathrm{mV} / \mathrm{sec}$ に統一し た。照合電極はすべて飽和塩化カリウム水溶液中の $\mathrm{Ag} /$ $\mathrm{AgCl}$ 電極を使用した。

\section{3. 実 験 結 果}

\section{$3.1 \mathrm{AlCl}_{3}$ 水溶液中の $\mathrm{Al}-\mathrm{Fe}$ 合金の腐食量}

溶液擋汼，窒素ガスによる脱気処理状態下の $0.1 \mathrm{M}$ $\mathrm{AlCl}_{3}$ 水溶液中での $\mathrm{Al}-\mathrm{Fe}$ 合金（試料番号 $\mathrm{F} 1 \sim \mathrm{F} 4$ ）の 腐食量を Fig. 1 亿示す。鉄添加量が $0.32 \mathrm{wt} \%$ の試料番 号 F1 の腐食量は $15 \sim 25 \mathrm{mg} / \mathrm{cm}^{2} / 10^{3} \mathrm{~h}$ で，鉄添加量が $1.45 \mathrm{wt} \%$ の試料番号 F4のそれは 26〜 $31 \mathrm{mg} / \mathrm{cm}^{2} / 10^{3} \mathrm{~h}$ を示し，鉄添加量が増えるにつれて腐食量は増加する。

$\mathrm{Al}-\mathrm{Fe}$ 合金中の鉄添加量と腐食量との間の相関関係を 調べた。有意水準 $5 \%$ で相関関係が認められ，その回帰 式は次のようになる。

$$
W=17.4+8.7[\mathrm{Fe}]
$$

ただし

$W: \mathrm{AlCl}_{3}$ 水溶液中の $\mathrm{Al}-\mathrm{Fe}$ 合金の腐食量 $\left(\mathrm{mg} / \mathrm{cm}^{2} /\right.$ $10^{3} \mathrm{~h}$ )

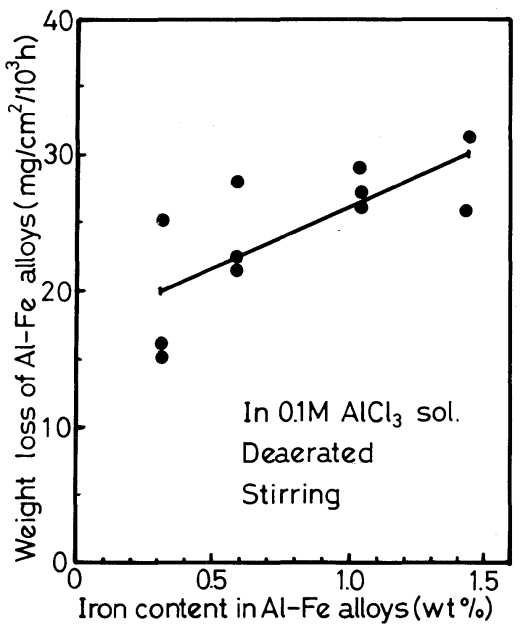

Fig. 1 Weight loss of $\mathrm{Al}-\mathrm{Fe}$ alloys in deaerated 0.1 $\mathrm{M} \mathrm{AlCl}{ }_{3}$ solution.

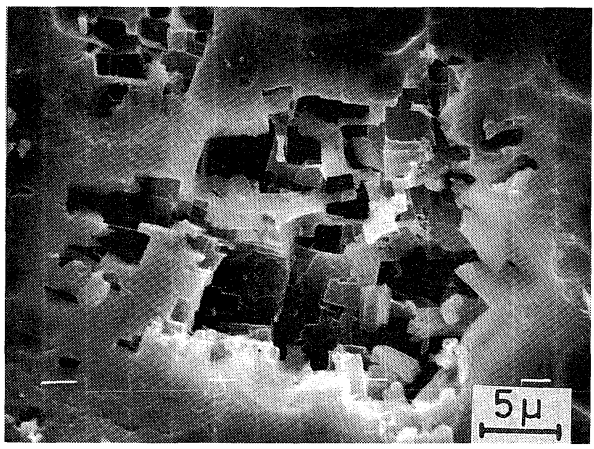

Fig. 2 SEM observation of corrsion surface on $\mathrm{Al}-$ Fe alloy (specimen No.: F3) in deaerated $0.1 \mathrm{M}$ $\mathrm{AlCl}_{3}$ solution.

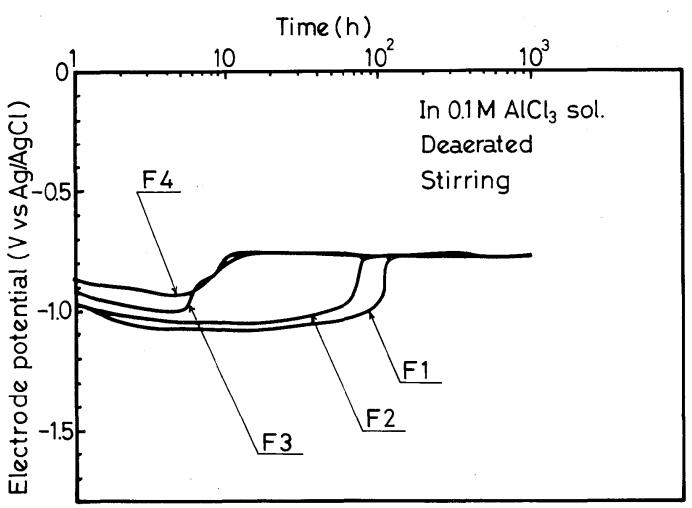

Fig. 3 Corrsion potential vs time curves for $\mathrm{Al}-\mathrm{Fe}$ alloys (specimen No.: F1 F4) in deaerated $0.1 \mathrm{M}$ $\mathrm{AlCl}_{3}$ solution.

$[\mathrm{Fe}]: \mathrm{Al}-\mathrm{Fe}$ 合金中の鉄添加量（wt\%）

$\mathrm{Al}-\mathrm{Fe}$ 合金中の $0.32 \sim 1.45 \mathrm{wt} \%$ の鉄添加量がその腐食 量に及ぼす寄与率を $\mathrm{dW} / \mathrm{d}[\mathrm{Fe}]$ とすれば， $\mathrm{AlCl}_{3}$ 水溶液 中のそれは $8.7 \mathrm{mg} / \mathrm{cm}^{2} / 10^{3} \mathrm{~h} / \mathrm{wt} \% \mathrm{Fe}$ とる。 $0.1 \mathrm{M}$ $\mathrm{NaCl}$ では $0.69 \mathrm{mg} / \mathrm{cm}^{2} / 10^{3} \mathrm{~h} / \mathrm{wt} \% \mathrm{Fe}$ であり5), $\mathrm{AlCl}_{3}$ 水 溶液中の腐食量の方が12.6倍と多くなっている。食孔内 溶液環境中における $\mathrm{Al}-\mathrm{Fe}$ 合金の溶解量はバルク環境 中のそれよりおよそ一桁大きいといえる。

実験終了後の表面 SEM 観察の結果を，試料番号 F3 を代表にとり，Fig. 2 に示す。表面には金属間化合物は ほとんど観察されず，孔食が起こっていたことを示す方 位ピットが存在している。

\section{$3.2 \mathrm{AlCl}_{3}$ 水溶液中の $\mathrm{Al}-\mathrm{Fe}$ 合金の腐食電位の経時} 変化

溶液摚汼，窒素ガスによる脱気処理状態下の $0.1 \mathrm{M}$ $\mathrm{AlCl}_{3}$ 水溶液中での $\mathrm{Al}-\mathrm{Fe}$ 合金（試料番号 $\mathrm{F} 1 \sim \mathrm{F} 4$ ）の 


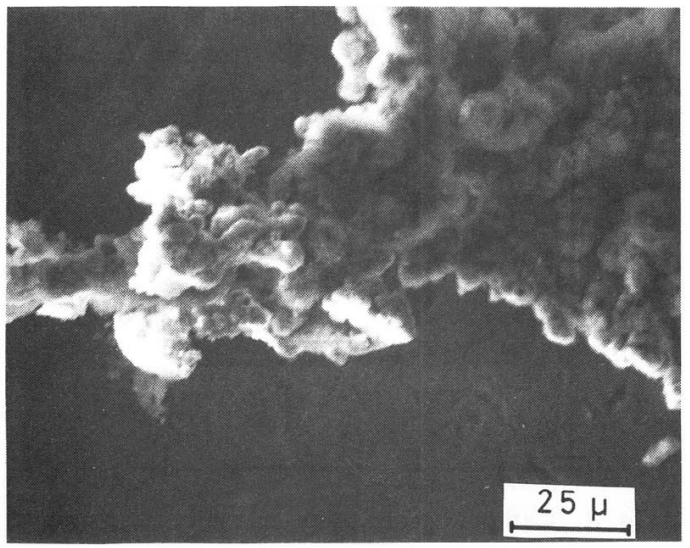

(a) : SEM

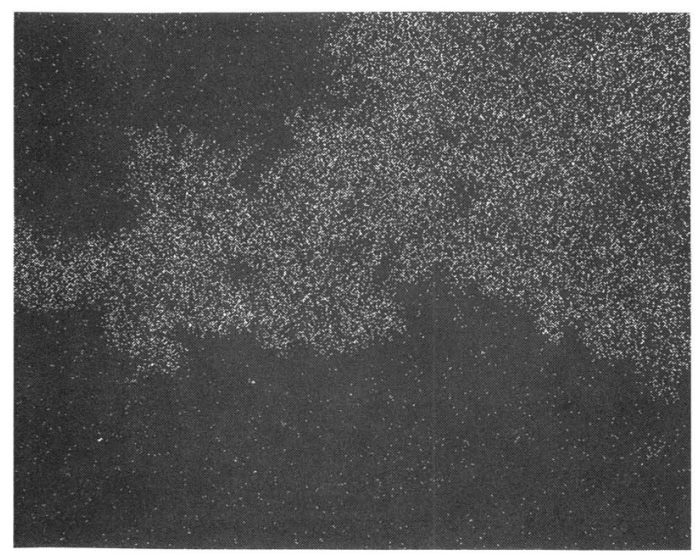

(b) : $\mathrm{Fe}-\mathrm{K} \alpha$

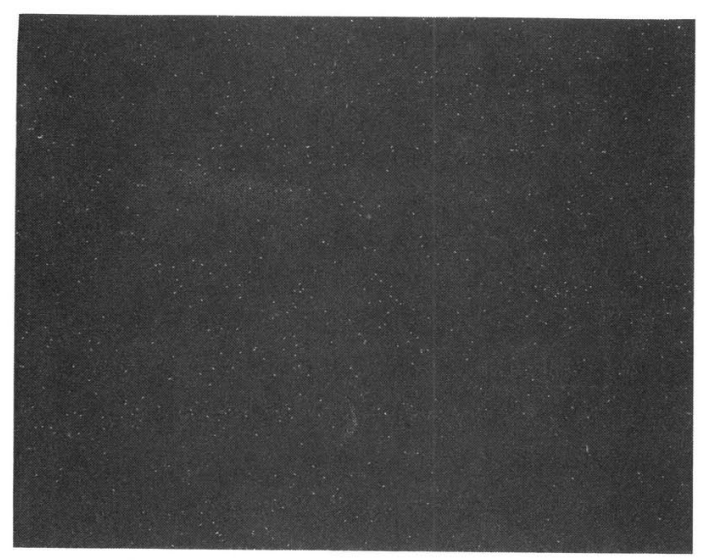

(c) : $\mathrm{Al}-\mathrm{K} \alpha$

Fig. $4(a) \sim(c)$ EPMA observation of corrsion product which existed on the surface of $\mathrm{Al}-\mathrm{Fe}$ alloy in deaerated $0.1 \mathrm{M} \mathrm{AlCl}_{3}$ solution.
腐食電位の経時変化をFig. 3 に示す。試料番号 F1 の腐 食電位は，浸漬後 1 時間から100時間まではー1.0 $-1.08 \mathrm{~V}$ を示し, その後の 900 時間は一 $-0.78 \mathrm{~V}$ の一定值 を示している。試料番号 F2 の腐食電位は試料番号 F1 とほほ同じ経緯を示すが， $-0.78 \mathrm{~V}$ の一定值を示すの は試料番号 F1のそれよりやや早く，浸漬後80時間を経 過してからである。試料番号 F3, F4 は試料浸漬後約 10 時問から-0.78 Vの一定値を示し，その期間は試料番 号 F3，F4 とも非常に長く，990時閒の長期にわたってい る。

腐食電位一 $0.78 \mathrm{~V}$ の一定值を示すまでの腐食電位は

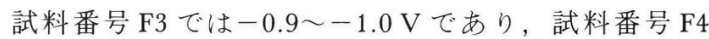
のそれはー0.88〜 - $0.93 \mathrm{~V}$ を示し, 鉄添加量の最も多い 試料番号 F4 が最も貴な電位域で変動している。

試料浸漬後，150時間経過時点での試料表面の目視観 察では, 試料番号 F1〜F4 の寸べての試料表面に黒褐色 の付着物が見られ，その表面で水素発生が起こっている ことが目視でも観察された。

実験終了後この黒褐色の付着物をこさぎ落とし，その 物質のEPMA 観察を行った。その結果をFig. 4(a), (b)，(c) に示す。Fig. 4(a)，(b)，(c)はそれぞれ SEM 像, $\mathrm{Fe}-\mathrm{K}_{\alpha}$ 面分布, $\mathrm{Al}-\mathrm{K}_{\alpha}$ 面分布を示す。 $\mathrm{Fe}^{-}-\mathrm{K}_{\alpha}, \mathrm{Al}-\mathrm{K}_{\alpha}$ 両 面分布より，この黒褐色の付着物中にはアルミニウムは ほとんど含まれておらず，またその成分は鉄であること がわかる。この付着物は脱落した $\mathrm{FeAl}_{3}$ 等の金属間化合 物ではなく，析出鉄である。

\section{$3.3 \mathrm{AlCl}_{3}$ 水溶液中での $\mathrm{Al}-\mathrm{Fe}$ 合金の分極曲線}

3.1 の腐食電位の経時変化の測定において, 試料番号 $\mathrm{F} 1 \sim \mathrm{F} 4$ の腐食電位がやや卑な電位域（約 $-1.0 \mathrm{~V}$ 前後） を示す浸漬初期と長期間一定值 $(-0.78 \mathrm{~V})$ を示す浸漬 後期の 2 領域が存在することを指摘した。そこで浸漬前 期，浸漬後期の電位域における分極曲線を，試料番号

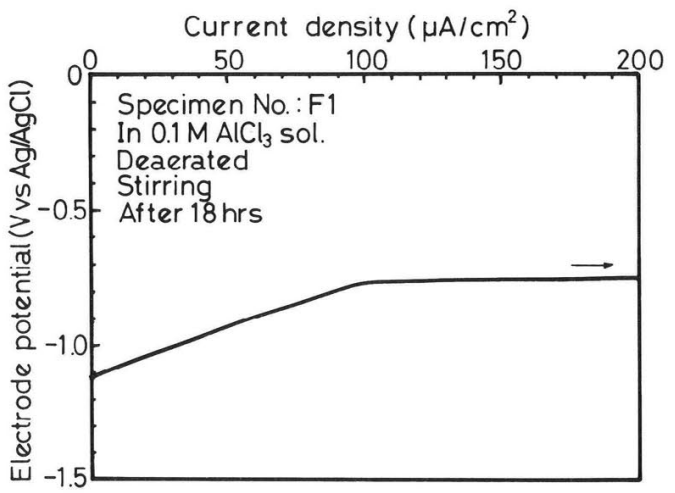

Fig. 5 Anodic polarization curve for $\mathrm{Al}-\mathrm{Fe}$ alloy (specimen No.: F1) in deaerated $0.1 \mathrm{M} \mathrm{AlCl}_{3}$ solution after immesion period $(18 \mathrm{hrs})$. 


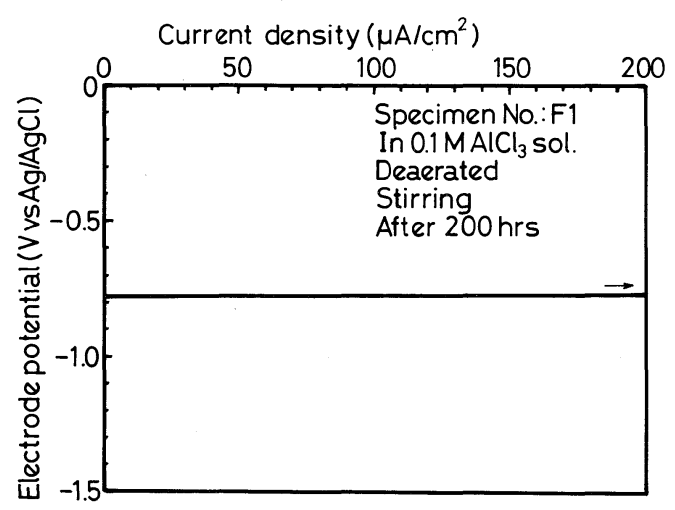

Fig. 6 Anodic polarization curve for $\mathrm{Al}-\mathrm{Fe}$ alloy (specimen No.: F1) in deaerated $0.1 \mathrm{M} \mathrm{AlCl}_{3}$ solution after immesion period $(200 \mathrm{hrs}$.).

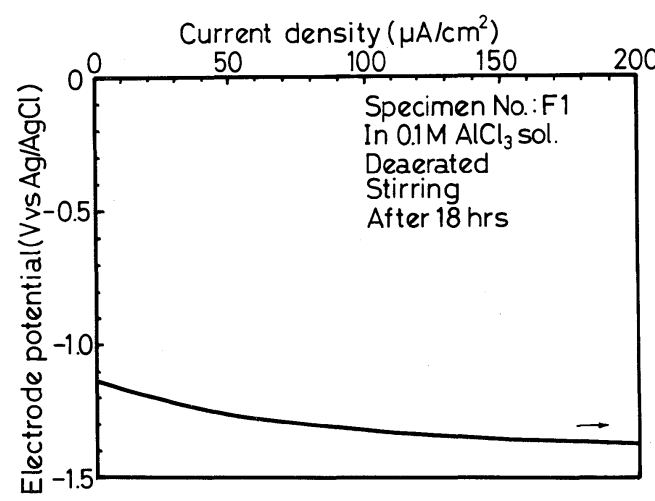

Fig. 7 Cathodic polarization curve for $\mathrm{Al}-\mathrm{Fe}$ alloy (specimen No.: F1) in deaerated $0.1 \mathrm{M} \mathrm{AlCl}_{3}$ solution after immesion period $(18 \mathrm{hrs})$.

F1を代表にとり, 調べてみた。溶液擋拌, 窒素ガスに

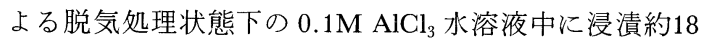
時間後のアノード分極曲線を Fig. 5 に，浸漬約200時間 後のそれをFig. 6 に示す。また，浸漬約18時間後のカ ソード分極曲線をFig. 7 に，浸漬後のそれをFig. 8 に 示す。

Fig. 5 と Fig. 6 を比較すると, その相違点は腐食電位 から孔食電位までの全面溶解域の有無にある。Fig. 5 に は全面溶解域が存在するが, Fig. 6 には存在しない。つ まり, Fig. 6 では腐食電位が孔食電位と一致しており, ほとんどアノード分極はなく容易に多大の孔食電流が流 れやすいことを示している。

カソード分極抵抗の傾向を示すFig. 7 と Fig. 8 を比 較すると, $-0.78 \mathrm{~V} \sim-1.1 \mathrm{~V}$ の電位域におけるカソー ド分極は浸漬後期の Fig. 8 のほらが浸漬初期の Fig. 7 よりやや大きいが分極時の電流の振動が常に観察される ことが特徵的である。

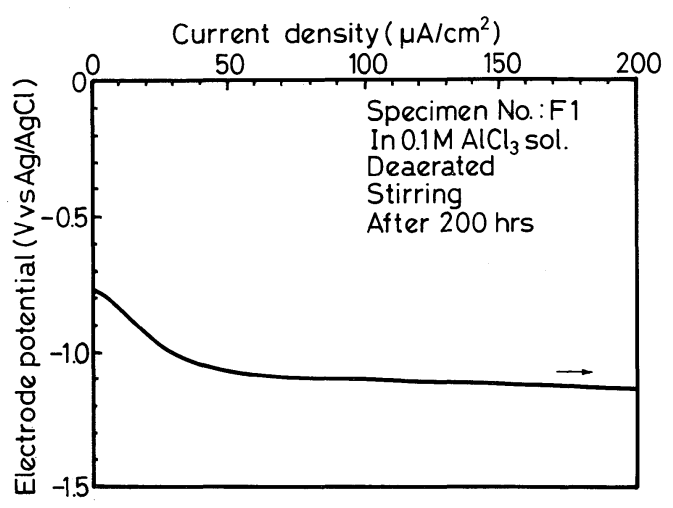

Fig. 8 Cathodic polarization curve for $\mathrm{Al}-\mathrm{Fe}$ alloy (specimen No.: F1) in deaerated $0.1 \mathrm{M} \mathrm{AlCl}_{3}$ solution after immesion period $(200 \mathrm{hrs})$.

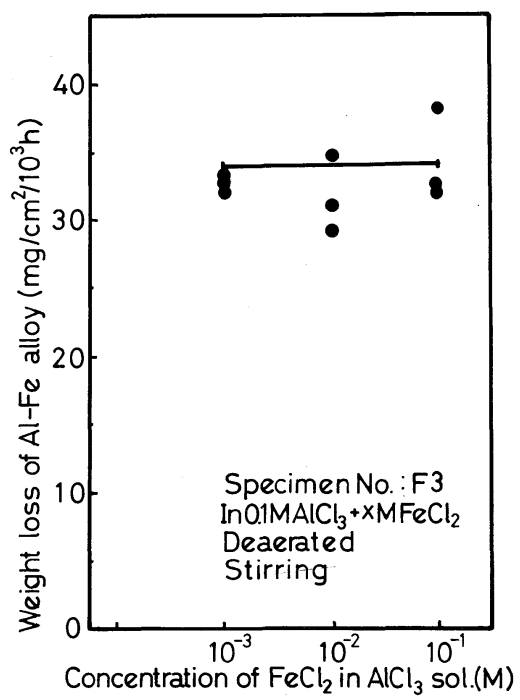

Fig. 9 Weight loss of $\mathrm{Al}-\mathrm{Fe}$ alloys (specimen No.: F3) in deaerated $0.1 \mathrm{M} \mathrm{AlCl}_{3}$ solution which contains $10^{-3} \sim 10^{-1} \mathrm{M} \mathrm{FeCl}_{2}$.

$3.4 \mathrm{Fe}$ (II) イオンを含有した塩化アルミニウム水 溶液中での $\mathbf{A l}-\mathbf{F e}$ 合金の腐食量

$\mathrm{Al}-\mathrm{Fe}$ 合金表面の金属間化合物は $\mathrm{AlCl}_{3}$ 水溶液内では 容易に溶解する ${ }^{6)}$ 。その結果生じた鉄イオンの挙動がそ の後の $\mathrm{Al}-\mathrm{Fe}$ 合金の腐食挙動に影響を及ぼす5)。そこ で，溶液中の鉄イオンの濃度差による $\mathrm{Al}-\mathrm{Fe}$ 合金の腐 食量の相違を調べてみた。溶液擋挥, 窒素ガスによる脱 気処理状態下の $0.1 \mathrm{M} \mathrm{AlCl}_{3}$ 水溶液中に $\mathrm{FeCl}_{2}$ を $10^{-3}$ $10^{-1} \mathrm{M}$ 添加した溶液環境中での $\mathrm{Al}-\mathrm{Fe}$ 合金の腐食量 を，試料番号 F3 を代表にとって，Fig. 9 に示す。

$\mathrm{FeCl}_{2}$ を $10^{-3} \mathrm{M}$ 添加した溶液環境中での試料番号 $\mathrm{F} 3$ の腐食量は $32 \sim 38 \mathrm{mg} / \mathrm{cm}^{2} / 10^{3} \mathrm{~h}, 10^{-1} \mathrm{M} \mathrm{FeCl}_{2}$ のそれ は33〜38 mg/ $\mathrm{cm}^{2} / 10^{3} \mathrm{~h}$ を示している。

$0.1 \mathrm{M} \mathrm{AlCl}_{3}$ 水溶液中に添加した $\mathrm{FeCl}_{2}$ の濃度と $\mathrm{Al}$ - 


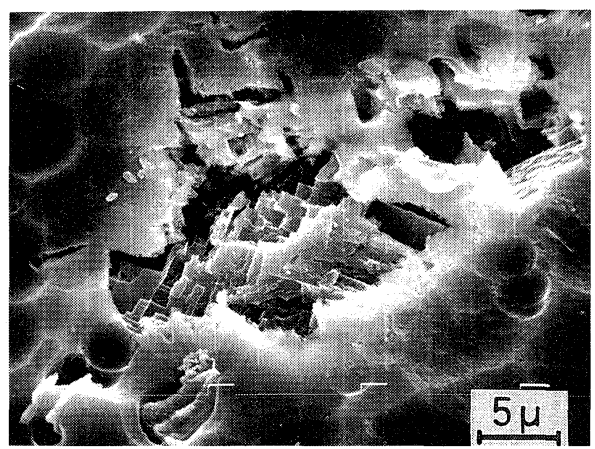

Fig. 10 SEM observation of corrsion surface on $\mathrm{Al}-$ Fe alloy (specimen No.: F3) in deaerated $0.1 \mathrm{M}$ $\mathrm{AlCl}_{3}$ solution which contains $10^{-2} \mathrm{M} \mathrm{FeCl}_{2}$.

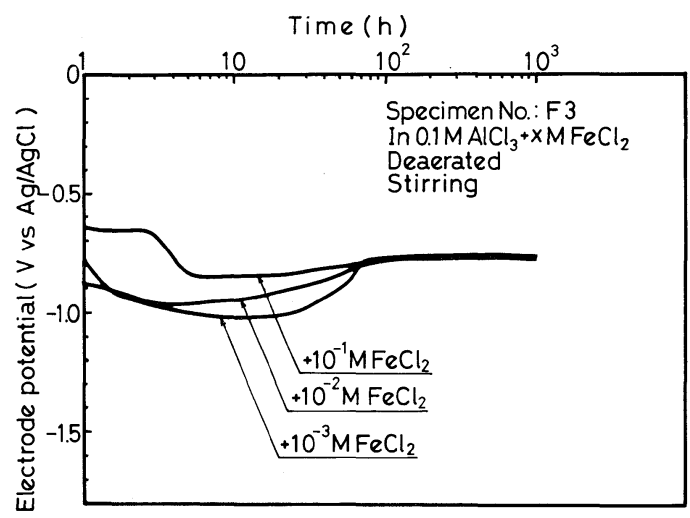

Fig. 11 Corrsion potential vs time curves for $\mathrm{Al}-\mathrm{Fe}$ alloys (specimen No.: F3) in deaerated $0.1 \mathrm{M} \mathrm{AlCl}_{3}$ solution which contains $10^{-3} \sim 10^{-1} \mathrm{M} \mathrm{FeCl}_{2}$.

$\mathrm{Fe}$ 合金（試料番号 F3）の腐食量との間の相関関係を求 めたが相関関係（有意水準 $5 \%$ ）は認められず，ほぼ一 定値を示している。

$$
W=34.5
$$

ただし，

$W: 0.1 \mathrm{M} \mathrm{AlCl}_{3}$ 水溶液中の $\mathrm{Al}-\mathrm{Fe}$ 合金（試料番号 F3）の腐食量 $\left(\mathrm{mg} / \mathrm{cm}^{2} / 10^{3} \mathrm{~h}\right)$

$0.1 \mathrm{M} \mathrm{AlCl}_{3}$ 水溶液中への $\mathrm{FeCl}_{2}$ 添加が $\mathrm{Al}-\mathrm{Fe}$ 合金の 腐食量に及ぼす効果は, その濃度範囲 $10^{-3} \sim 10^{-1} \mathrm{M}$ で は一定值 $34.5 \mathrm{mg} / \mathrm{cm}^{2} / 10^{3} \mathrm{~h}$ をとるとされる。

実験終了後の表面 SEM 観察結果を, $\mathrm{FeCl}_{2}$ 濃度 $10^{-2}$ Mの場合を代表にとって, Fig. 10 示す。Fig. 2 と同じ ような方位ピットの存在が観察され, 孔食が起こってい たことを示している。

$3.5 \mathrm{Fe}(\mathrm{II})$ イオンを添加した $\mathrm{AlCl}_{3}$ 水溶液中での Al-Fe 合金の腐食電位の経時変化

溶液撹汼, 窒素ガスによる脱気処理状態下の $0.1 \mathrm{M}$
$\mathrm{AlCl}_{3}$ 水溶液中に $\mathrm{FeCl}_{2}$ を $10^{-3} \sim 10^{-1} \mathrm{M}$ 添加した溶液環 境中での $\mathrm{Al}-\mathrm{Fe}$ 合金の腐食電位の経時変化の結果を, 試料番号 F3 を代表にとって，Fig. 11 に示す。 $\mathrm{FeCl}_{2}$ を $10^{-3} \mathrm{M}$ 添加した場合の腐食電位は浸漬後 10 時間から70 時間までは約－0.9V〜ー1.2V を示し，その後の930時 間はー0.78Vの一定值を示している。 $\mathrm{FeCl}_{2}$ を $10^{-2} \mathrm{M}$ 添加した場合の腐食電位は， $10^{-3} \mathrm{M} \mathrm{FeCl}_{2}$ 添加の場合 ほぼ同じ経緯を示す。 $\mathrm{FeCl}_{2}$ を $10^{-1} \mathrm{M}$ 添加した場合の 腐食電位は，浸漬後 5 時間は特異な変化を示すが，その 後は $10^{-3} \mathrm{M}, 10^{-2} \mathrm{M}$ 添加した場合とほぼ同じような経 緯を示す。浸漬10時間以降の $\mathrm{Al}-\mathrm{Fe}$ 合金（試料番号 F3） の腐食電位は, $\mathrm{FeCl}_{2}$ の濃度が高くなるにつれて貴に移 行する。つまり, 浸漬10時間目の腐食電位は, $\mathrm{FeCl}_{2}$ の 濃度が $10^{-3} \mathrm{M}$ の時 $-1.02 \mathrm{~V}, 10^{-2} \mathrm{M}$ ではー $0.94 \mathrm{~V}$, $10^{-1} \mathrm{M}$ ではー $0.85 \mathrm{~V}$ と $\mathrm{FeCl}_{2}$ の濃度が増えるにつれて 腐食電位は貴に移行する。 $-0.78 \mathrm{~V}$ の一定值を示すの は $\mathrm{FeCl}_{2}$ の濃度 $10^{-3} \mathrm{M}, 10^{-2} \mathrm{M}, 10^{-1} \mathrm{M}$ 共変らず, 浸漬 後70時間を経過してからである。

浸漬後100時間位経ってから $10^{-1} \mathrm{M} \mathrm{FeCl}_{2}$ 添加の試料 表面には肉眼で分かるほどの黒褐色の付着物が見られ た。その付着物は試料表面から離脱し，マグネチックス ターラに付着したことから，この黒褐色の付着物は磁性 を持っていることが分かった。 $\mathrm{FeAl}_{3}$ は汪とんど磁性を 持たないことから，この黒褐色の付着物は $\mathrm{Al}-\mathrm{Fe}$ 合金 から脱落した $\mathrm{FeAl}_{3}$ ではなく, 溶液から析出した鉄であ る。

\section{$3.6 \mathrm{AlCl}_{3}$ 水溶液中での鉄の分極曲線}

$3.1 ， 3.2,3.5$ 上り, $\mathrm{AlCl}_{3}$ 水溶液中の $\mathrm{Fe}(\mathrm{II})$ イオン は $\mathrm{Al}-\mathrm{Fe}$ 合金表面に析出することが判明した。そこで $\mathrm{AlCl}_{3}$ 水溶液中での析出鉄の電気化学的性質を調べるた

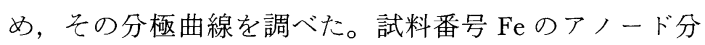
極曲線をFig. 12 に, カソード分極曲線をFig. 13 に示

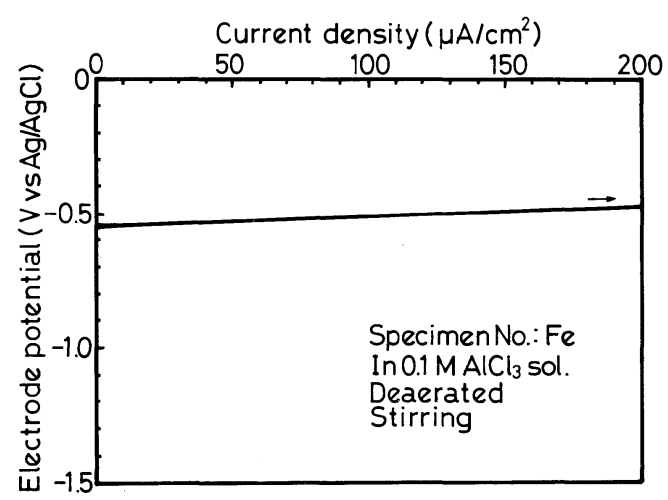

Fig. 12 Anodic polarization curve for iron (specimen No.: Fe) in deaerated $0.1 \mathrm{M} \mathrm{AlCl}_{3}$ solution. 


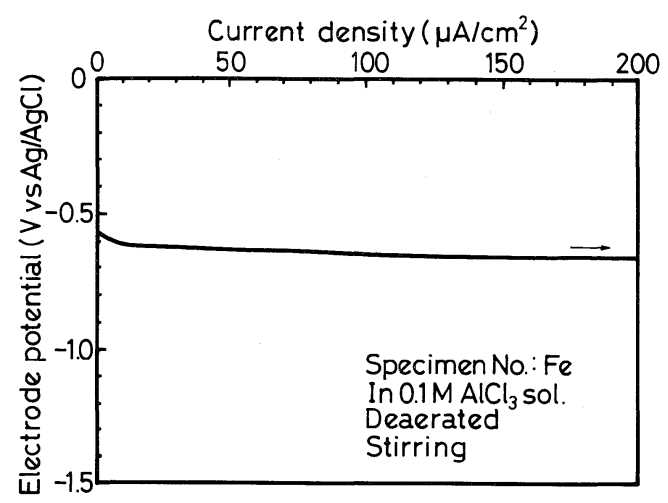

Fig. 13 Cathodic polarization curve for iron (specimen No.: $\mathrm{Fe}$ ) in deaerated $0.1 \mathrm{M} \mathrm{AlCl}_{3}$ solution.

す。腐食電位はー0.55Vであり，この電位はFig. 5, Fig. 6 の孔食電位一 $-0.78 \mathrm{~V}$ より貴である。また, 試料番 号 $\mathrm{Fe}$ の表面で起こるアノード反応, カソード反応とも ほとんど分極しない系である。

\section{4. 考察}

\section{$4.1 \mathrm{AlCl}_{3}$ 水溶液中での鉄イオンの挙動}

$\mathrm{Al}-\mathrm{Fe}$ 合金表面に露呈している $\mathrm{FeAl}_{3}$ 系金属間化合物 は, $\mathrm{AlCl}_{3}$ 水溶液中ではほとんど分極せず，容易にア， ード溶解する ${ }^{3)}$ 。このアノード溶解によって生じた鉄イ オンの状態は, その時の腐食電位と電極界面の $\mathrm{pH}$ によ って熱力学的に規定される7)。本実験の腐食条件 (Fig. 3 参照), つまり腐食電位 $-1.08 \mathrm{~V} \sim-0.78 \mathrm{~V}$, バルク溶 液の $\mathrm{pH}$ 值約 3 の条件を電位〜 $\mathrm{pH}$ 図に当てはめると熱 力学的に存在する可能性のある化学種は $\mathrm{Fe}$ (II) と $\mathrm{Fe}$ になる。これらの化学種の電気化学反応式は次式のよう になる。

$$
\begin{aligned}
& \mathrm{Fe}^{2+}+2 \mathrm{e}=\mathrm{Fe} \downarrow \\
& \mathrm{E}=-0.64+0.0295 \log \left(\mathrm{Fe}^{2+}\right)
\end{aligned}
$$
ただし，

$\mathrm{E}:(3)$ 式の平衡電位 ( $\mathrm{V}$ vs $\mathrm{Ag} / \mathrm{AgCl}$ )

(3) 式の電極電位に影響を及ぼすのは溶液中の鉄イオ ン濃度; $\left(\mathrm{Fe}^{2+}\right)$ だけである。本実験の $\mathrm{AlCl}_{3}$ 水溶液中の 鉄イオン濃度 $;\left(\mathrm{Fe}^{2+}\right)$ は試料側の $\mathrm{Al}-\mathrm{Fe}$ 合金中の鉄添 加量 $;[\mathrm{Fe}]$ に応じて高くなっているはずである。つま り, $\mathrm{Al}-\mathrm{Fe}$ 合金中の鉄添加量が多ければ多い汪ど $\mathrm{AlCl}_{3}$ 水溶液中へ溶出する鉄イオンの量も多いことが予想さ れ, 次式が考兄られる。

$$
\left(\mathrm{Fe}^{2+}\right) \propto[\mathrm{Fe}]
$$
ただし，

$\left(\mathrm{Fe}^{2+}\right): \mathrm{AlCl}_{3}$ 水溶液中の鉄イオンの濃度 $(\mathrm{M})$

$[\mathrm{Fe}]: \mathrm{Al}-\mathrm{Fe}$ 合金中の鉄添加量 (wt \%)

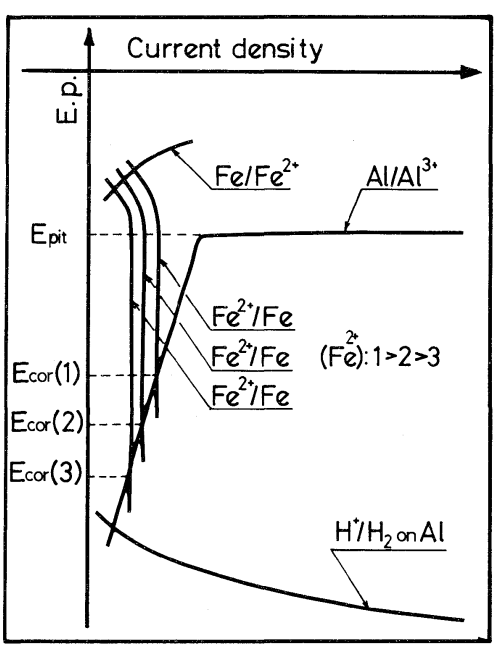

Fig. 14(a) Schematic explanation of corrosion potential for $\mathrm{Al}-\mathrm{Fe}$ alloys in deaerated $0.1 \mathrm{M} \mathrm{AlCl}_{3}$ solution.

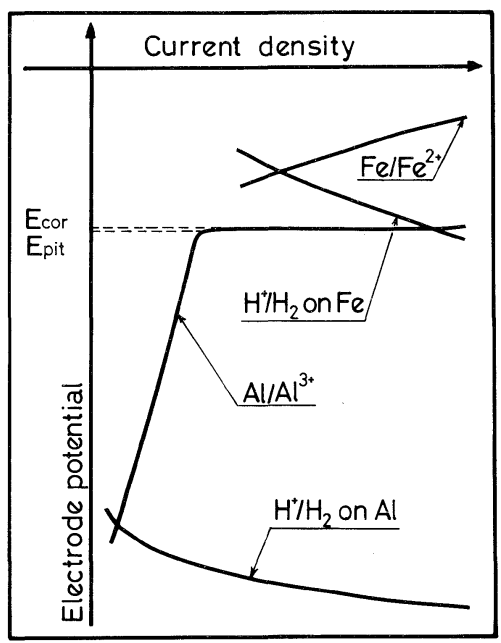

Fig. 14(b) Schematic explanation of corrosion potential for $\mathrm{Al}-\mathrm{Fe}$ alloys in deaerated $0.1 \mathrm{M} \mathrm{AlCl}_{3}$ solution.

(4) 式の正確な関数関係を求めるには非常な困難を伴う が，少なくとも試料番号 F1よりは試料番号 F2, 試料番 号 F2 よりは試料番号 F3, 試料番号 F3 よりは試料番号 F4の方が溶出した鉄イオン濃度は高くなっているもの と考えられる。したがって，(3)式の影響が強く現れて いる電位域は, $\mathrm{Al}-\mathrm{Fe}$ 合金中の鉄含有量に応じて腐食電 位に差が現れている電位域と考えられる。この電位域 は, 浸漬初期に該当する。つまり, 浸漬初期の反応(3) 式は, $\mathrm{Al}-\mathrm{Fe}$ 合金中の鉄添加量を変えた場合の Fig. 3 あ るいは $\mathrm{AlCl}_{3}$ 水溶液の鉄イオンの濃度を変えた場合の Fig. 11 の浸漬初期に現れている現象に対応するものと 
考えられる。

(3)式の析出によって生じた鉄は浸漬後期のー0.78 V 一定値を示す腐食電位において安定に存在でき, その表 面で水素イオンの還元反応が起こる。この析出鉄表面で 起こる水素イオンの還元反応の電極電位はー0.55 Vで あり, $0.1 \mathrm{M} \mathrm{AlCl}_{3}$ 水溶液中のアルミニウムの孔食電位 のー0.78 Vより貴であるため, 容易にアルミニウム母 地の孔食反応に対するカソード部となり得る。しかもこ の反応は, Fig. 13 からも分かる通り, ほとんど分極し ない系であり，アルミニウムの孔食反応は激しく進行す る。

\section{$4.2 \mathrm{AlCl}_{3}$ 水溶液中での $\mathrm{Al}-\mathrm{Fe}$ 合金の腐食電位の解 釈}

$0.1 \mathrm{M} \mathrm{AlCl}_{3}$ 水溶液中の $\mathrm{Al}-\mathrm{Fe}$ 合金の腐食電位を $-0.8 \mathrm{~V} \sim-1.0 \mathrm{~V}$ を示す浸漬初期と $-0.78 \mathrm{~V}$ の一定值 を示す浸漬後期に分けて定性的に考察する。（Fig. 14 (a)，(b)参照)

浸漬初期の腐食電位は, Fig. 14(a)よりアルミニウム 母地の全面溶解域と (3) 式のカソード反応が起こってい る電位域である。（3）式の反応は非常に遅く，また鉄イ オンの供給律速になるので, 腐食電位は(4)式の制約を 受ける。すなわち, Fig. 3 における鉄添加量の少ない試 料番号 F1 やFig. 11 に拈ける鉄イオン濃度の低い方が 卑な電位を示すことになる。

浸漬後期の腐食電位は Fig. 14(b)より, アルミニウム 母地の孔食溶解と (3) 式によって生じた析出鉄の表面で 起こる水素イオンのカソード反応が起こっている電位域 である。この電位域は一 $0.78 \pm 0.02 \mathrm{~V}$ の一定值を長時間 示していることが特徵的である。例えば，試料番号 F1 では約 900 時間, 試料番号 F2 では920時間, 試料番号 F3，F4 では990時間である。このような長時間腐食電位
が一定値を示す電位は孔食電位以外には考えられない。 その上, Fig. 6 より,この-0.78 Vの電位は0.1 $\mathrm{M} \mathrm{AlCl}_{3}$ 水溶液中の $\mathrm{Al}-\mathrm{Fe}$ 合金の孔食電位と一致していること からも, 浸漬後期の腐食電位はアルミニウム母地の孔食 電位と一致しているものと考えられる。

\section{5. 結言}

脱気した $0.1 \mathrm{M} \mathrm{AlCl}_{3}$ 水溶液中へ $\mathrm{Al}-\mathrm{Fe}$ 合金を浸漬し, その腐食電位を長期間調べた結果, 以下のことが判明し た。

(1) $\mathrm{Al}-\mathrm{Fe}$ 合金表面の $\mathrm{FeAl}_{3}$ 系金属間化合物中の鉄は $\mathrm{AlCl}_{3}$ 水溶液中でカソード析出する。

（2）このカソード析出した鉄は, その表面で起こる水 素イオンのカソード反応を容易にする。

(3)（2)のカソード反応はアルミニウム母地を孔食状態 に保持し, その腐食電位は孔食電位 $-0.78 \mathrm{~V}$ の一 定値を示す。

終りに，本実験の供試材を提供して頂いた三菱アルミ ニウム(株)技術研究所の当摩建氏に感謝の意を表します。

本研究の一部は財)實吉奖学会 (Saneyoshi Scholarship Foundation）の助成金によったことを記し，謝意を表し ます。

\section{参 考 文 献}

1）例えば, 増子：第18回工業物理化学講習会「金属表 面の物理化学」p. 33 .

2) 当摩, 山田 : 軽金属, $30,(1980), 85$.

3）世利, 増子：軽金属, 34, (1984), 41.

4）世利, 田頭：軽金属, 36, (1986), 477 .

5）世利, 田頭：軽金属投稿中.

6）世利，増子：軽金属，32, (1982), 303.

7) M. Pourbaix: Atlas of Electrochemical Equilibria (1966), Pergamon press. 